Article

\title{
Aspidoptoids A-D: Four New Diterpenoids from Aspidopterys obcordata Vine
}

\author{
Peng Sun ${ }^{1,2,+}$, Dong-Hua Cao ${ }^{1,2,+}$, Yi-Dian Xiao ${ }^{3,4}$, Zong-Yi Zhang ${ }^{1,2}$, Jia-Nan Wang ${ }^{1,2}$, \\ Xiao-Cui Shi ${ }^{1,2}$, Chun-Fen Xiao ${ }^{1}$, Hua-Bin $\mathrm{Hu}^{1}$ and You-Kai $\mathrm{Xu}^{1, *}$ \\ 1 CAS Key Laboratory of Tropical Plant Resources and Sustainable Use, Xishuangbanna Tropical Botanical \\ Garden, Chinese Academy of Sciences, Menglun 666303, China; sunpeng@xtbg.ac.cn (P.S.); \\ caodonghua@xtbg.ac.cn (D.-H.C.); zhangzongyi@xtbg.ac.cn (Z.-Y.Z.); wangjianan@xtbg.ac.cn (J.-N.W.); \\ shixiaocui@xtbg.ac.cn (X.-C.S.); xiaocf@xtbg.ac.cn (C.-F.X.); huhb@xtbg.ac.cn (H.-B.H.) \\ 2 University of Chinese Academy of Sciences, Beijing 100049, China \\ 3 School of Chemical Science and Technology, Key Laboratory of Medicinal Chemistry for Nature Resources, \\ Ministry of Education, Yunnan University, Kunming 650019, China; xiaoyidian@mail.kib.ac.cn \\ 4 State Key Laboratory of Phytochemistry and Plant Resources in West China, Kunming Institute of Botany, \\ Chinese Academy of Sciences, Kunming 650201, China \\ * Correspondence: xyk@xtbg.ac.cn; Tel.: +86-691-871-5071 \\ + These authors contributed equally to this work.
}

Received: 25 December 2019; Accepted: 22 January 2020; Published: 25 January 2020

check for updates

\begin{abstract}
Four new diterpenoids, named aspidoptoids A-D (1-4), together with two known analogues (5-6) were isolated from Aspidopterys obcordata vine. Aspidoptoids A-B (1-2) are the first examples of phenylethylene-bearing 20-nor-diterpenoids of which aspidoptoid B (2) possesses a rare 3,10-oxybridge. Their structures and absolute configuration were determined by extensive spectroscopic analyses (IR, HRESIMS, 1D and 2D NMR) and electronic circular dichroism (ECD) calculation. In addition, all the isolates were evaluated for their cytotoxic activities and inhibitory effects on the nitric oxide (NO) production.
\end{abstract}

Keywords: Aspidopterys obcordata; Malpighiaceae; norditerpeniod; cytotoxic activity; anti-inflammatory activity

\section{Introduction}

Aspidopterys genus (Malpighiaceae family) has approximately 20 species, mainly distributed in the regions of tropical Asia, of which nine species and one variant grow in China. Aspidopterys obcordata Hemsl is a woody liana in 600-1600 m habitats including sparse forests, valley shrub forests, or mountains in Hainan and Yunnan provinces, China [1]. The stems and branches of $A$. obcordata have been traditionally used as folk medicine by Dai people in Xishuangbanna, Southwest China, for treating various diseases such as urinary tract infections, acute and chronic nephritis, cystitis, pyelitis, urinary calculi, rheumatic bone pain, postpartum body deficiency, and anorexia [2,3]. To date, just a few phytochemical and pharmacological studies have been conducted on this plant. Previous phytochemical investigations on $A$. obcordata led to the isolation of triterpenes, sterols, tannins, and polyoxypregnane glycosides [4-7]. Among them, polyoxypregnane glycosides have been reported to exhibit anti-urolithiatic [8] and anti-tumor activities [6]. In continuing the search for structurally diverse and biologically interesting metabolites from Dai medicine plants, the chemical components of A. obcordata vine were investigated. As a result, four new diterpenoids, named aspidoptoids A-D (1-4), together with two known analogues (5-6) were isolated from the 95\% EtOH extract of A. obcordata vine. Aspidoptoids A-B (1-2) are the first example of phenylethylene-bearing 20-nor-diterpenoid of which aspidoptoids B (2) possesses a rare 3,10-oxybridge (Figure 1). All the isolates were tested for their 
cytotoxic activities against human myeloid leukemia (HL-60), hepatocellular carcinoma (SMMC-7721), lung cancer (A-549), breast cancer (MCF-7), and colon cancer (SW480) cell lines and NO inhibitory effects on lipopolysaccharide (LPS)-stimulated RAW 264.7 macrophages cells. Herein, we report the isolation, structure elucidation, and biological evaluation of these compounds.

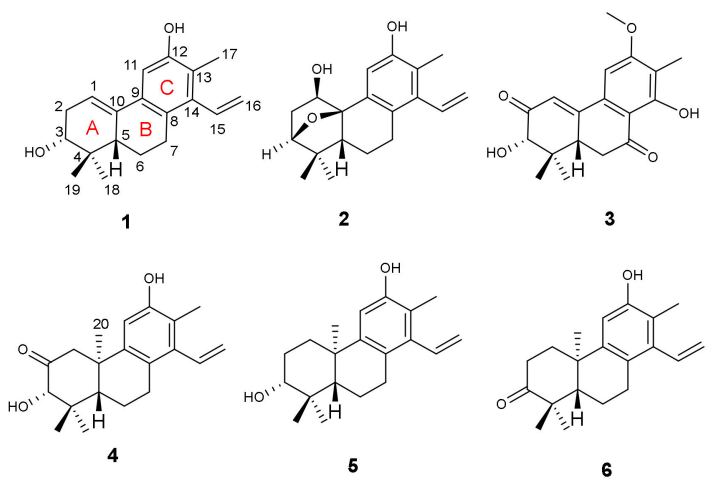

Figure 1. The structures of compounds 1-6.

\section{Results and Discussion}

Compound 1, a yellow powder, possessed a molecular formula $\mathrm{C}_{19} \mathrm{H}_{24} \mathrm{O}_{2}$ as determined by the negative HRESIMS peak at $m / z 283.1704[\mathrm{M}-\mathrm{H}]^{-}$(calcd. for $\mathrm{C}_{19} \mathrm{H}_{23} \mathrm{O}_{2}, 283.1704$ ), corresponding to eight degrees of unsaturation. The IR absorptions indicated the presence of hydroxyl $\left(3430 \mathrm{~cm}^{-1}\right) \mathrm{and}^{-}$ olefinic $\left(1630 \mathrm{~cm}^{-1}\right)$ groups. The 1D NMR spectra of 1 displayed the occurrence of 19 carbon signals which were further classified by the DEPT experiment as three methyls, four methylenes (one olefinic), five methines (three olefinic and one oxygenated), and seven quaternary carbons (six olefinic and one aliphatic) (Tables 1 and 2). In addition, a terminal vinyl $\left(\delta_{\mathrm{H}} 6.61, \mathrm{dd}, J=17.9,11.4 \mathrm{~Hz}, \mathrm{H}-15 ; \delta_{\mathrm{H}}\right.$ $5.55, \mathrm{dd}, J=11.4,2.0 \mathrm{~Hz}, \mathrm{H}-16 \alpha ; \delta_{\mathrm{H}} 5.17, \mathrm{dd}, J=17.9,2.0 \mathrm{~Hz}, \mathrm{H}-16 \beta ; \delta_{\mathrm{C}} 135.3$ and 120.1), three singlet methyls $\left(\delta_{\mathrm{H}} 2.19,1.11\right.$, and 0.77 , all s; $\delta_{\mathrm{C}} 24.4,13.4$, and 13.1), a trisubstituted double bond $\left(\delta_{\mathrm{H}} 6.18, \mathrm{t}\right.$, $J=3.1 \mathrm{~Hz} ; \delta_{\mathrm{C}} 134.5$ and 116.5$)$ and one penta-substituted benzene ring $\left(\delta_{\mathrm{H}} 7.03, \mathrm{~s} ; \delta_{\mathrm{C}} 152.1,139.5,132.9\right.$, $127.3,121.3$, and 108.3) were easily distinguished by analysis of the NMR data (Tables 1 and 2). Those identified functionalities accounted for 5 out of 8 degrees of unsaturation; the remaining required three additional rings in 1. Comparing its 1D NMR data with those of spruceanol (5), a cleistanthane diterpenoid reported from Cunuria spruceana [9], indicated that they had the very similar rings A, B, and $\mathrm{C}$, with the differences being the presence of $\Delta^{1,10}$ double bond in $\mathbf{1}$ and the absence of $\mathrm{CH}_{2}-1$ $\left(\delta_{\mathrm{H}} 3.38, \mathrm{t}, J=6.8 \mathrm{~Hz} ; \delta_{\mathrm{C}} 25.4\right)$ and $\mathrm{CH}_{3}-20\left(\delta_{\mathrm{H}} 1.19, \mathrm{~s} ; \delta_{\mathrm{C}} 24.8\right)$ in 5 . The proposition was further confirmed by $2 \mathrm{D}$ NMR experiments. The ${ }^{1} \mathrm{H}-{ }^{1} \mathrm{H}$ COSY correlations constructed two partial structures of $-\mathrm{CH}-\mathrm{CH}_{2}-\mathrm{CH}(\mathrm{O})-$ and $-\mathrm{CH}-\mathrm{CH}_{2}-\mathrm{CH}_{2}-$ in 1 as shown with bold lines in Figure 2. Moreover, the HMBC correlations (Figure 2) of both methyl protons at $\delta_{\mathrm{H}} 0.77\left(\mathrm{H}_{3}-18\right)$ and $1.11\left(\mathrm{H}_{3}-19\right)$ with $\mathrm{C}-3$ $\left(\delta_{\mathrm{C}} 74.9\right) / \mathrm{C}-4\left(\delta_{\mathrm{C}} 37.2\right) / \mathrm{C}-5\left(\delta_{\mathrm{C}} 46.2\right)$; another methyl at $\delta_{\mathrm{H}} 2.19\left(\mathrm{H}_{3}-17\right)$ with $\mathrm{C}-8\left(\delta_{\mathrm{C}} 127.3\right) / \mathrm{C}-11\left(\delta_{\mathrm{C}}\right.$ $108.3) / \mathrm{C}-12\left(\delta_{\mathrm{C}} 152.1\right) / \mathrm{C}-13\left(\delta_{\mathrm{C}} 121.3\right) / \mathrm{C}-14\left(\delta_{\mathrm{C}} 139.5\right)$; the aliphatic methine at $\delta_{\mathrm{H}} 2.02(\mathrm{H}-5)$ with C-4 $\left(\delta_{\mathrm{C}} 37.2\right) / \mathrm{C}-6\left(\delta_{\mathrm{C}} 24.0\right) / \mathrm{C}-7\left(\delta_{\mathrm{C}} 28.9\right) / \mathrm{C}-9\left(\delta_{\mathrm{C}} 132.9\right) / \mathrm{C}-10\left(\delta_{\mathrm{C}} 134.5\right)$; the aromatic proton at $\delta_{\mathrm{H}} 7.03(\mathrm{H}-11)$ with C-7/C-8/C-9/C-10/C-12/C-13 furnished the typical fused A/B/C-ring system of the diterpenoid core like spruceanol. The location of the $\Delta^{1,10}$ double bond was further confirmed by HMBC correlations from H-1 $\left(\delta_{\mathrm{H}} 6.18\right)$ to C-2 (32.3)/C-3 $\left(\delta_{\mathrm{C}} 74.9\right) / \mathrm{C}-5\left(\delta_{\mathrm{C}} 46.2\right) / \mathrm{C}-10\left(\delta_{\mathrm{C}} 134.5\right)$, combined with ${ }^{1} \mathrm{H}-{ }^{1} \mathrm{H}$ COSY correlations $\mathrm{H}-1\left(\delta_{\mathrm{H}} 6.18, \mathrm{t}, J=3.1 \mathrm{~Hz}\right)$ with $\mathrm{H}-2\left(\delta_{\mathrm{H}} 2.16\right.$, ddd, $J=10.2,6.5,3.1 \mathrm{~Hz}$ and $\left.\delta_{\mathrm{H}} 2.47, \mathrm{~m}\right)$. These observations suggested 1 to be the first example of phenylethylene-bearing 20-nor-diterpenoid with a $\Delta^{1,10}$ double bond.

The relative configuration of $\mathbf{1}$ was proposed on the basis of ROESY data (Figure 3) and by comparison with that of spruceanol. The ROESY correlations of $\mathrm{H}-2 \alpha / \mathrm{H}_{3}-18, \mathrm{H}-6 \alpha / \mathrm{H}-7 \alpha$, and $\mathrm{H}-6 \alpha / \mathrm{H}_{3}-18$ indicated that these protons adopt the same orientation, whereas those of $\mathrm{H}-2 \beta / \mathrm{H}-3, \mathrm{H}-3 / \mathrm{H}-5, \mathrm{H}-3 / \mathrm{H}_{3}-19$, and $\mathrm{H}-5 / \mathrm{H}_{3}-19$ placed these protons on the opposite face of the ring system. The absolute configuration 
of 1 was determined by quantum chemical TDDFT calculation of its theoretical ECD spectrum. In the 200-400 nm regions, both the experimental ECD spectrum and the calculated one for 1 showed a negative first Cotton effect at approximately $255 \mathrm{~nm}$ and showed the the same trend for other parts (Figure 4). Therefore, qualitative analysis of the calculated and experimental ECD spectra allowed the assignments of the absolute configuration of $\mathbf{1}$ as $3 R, 5 S$. The structure of $\mathbf{1}$ was thus established and named aspidoptoid A as depicted in Figure 1.

Table 1. ${ }^{1} \mathrm{H}(600 \mathrm{MHz}) \mathrm{NMR}$ data for compounds $1-4$ in $\mathrm{CDCl}_{3}$.

\begin{tabular}{|c|c|c|c|c|}
\hline \multirow{2}{*}{ No. } & 1 & 2 & 3 & 4 \\
\hline & $\delta_{\mathrm{H}}$, mult. $(J$ in $\mathrm{Hz})$ & $\delta_{\mathrm{H}}$, mult. $(J$ in $\mathrm{Hz})$ & $\delta_{\mathrm{H}}$, mult. $(J$ in $\mathrm{Hz})$ & $\delta_{\mathrm{H}}$, mult. $(J$ in $\mathrm{Hz})$ \\
\hline $1 \alpha$ & $6.18, \mathrm{t}(3.1)$ & 4.32, dd $(10.3,3.6)$ & $6.83, \mathrm{~d}(2.7)$ & 3.05, d (12.3) \\
\hline $1 \beta$ & & & & $2.63, \mathrm{~d}(12.3)$ \\
\hline $2 \alpha$ & 2.16, ddd $(10.2,6.5,3.1)$ & $1.81, \mathrm{dd}(13.2,3.6)$ & & \\
\hline $2 \beta$ & $2.47, \mathrm{~m}$ & $2.30, \mathrm{~m}$ & & \\
\hline 3 & 3.60 , overlapped & $3.86, \mathrm{~d}(5.9)$ & $4.09, \mathrm{~s}$ & $3.97, \mathrm{~s}$ \\
\hline 5 & $2.02, \mathrm{~m}$ & $2.38, \mathrm{dd}(13.6,4.8)$ & 3.15, ddd $(13.5,5.2,2.7)$ & $1.96, \mathrm{dd}(12.2,2.0)$ \\
\hline $6 \alpha$ & 1.37, ddd $(26.3,7.2,2.9)$ & $1.28, \mathrm{~m}$ & $2.73, \mathrm{dd}(16.4,13.5)$ & 1.75, ddd $(25.2,12.2,6.0)$ \\
\hline $6 \beta$ & $2.03, \mathrm{~m}$ & $1.78, \mathrm{~m}$ & $2.88, \mathrm{dd}(16.4,5.2)$ & $2.01, \mathrm{~m}$ \\
\hline $7 \alpha$ & 2.87, ddd $(16.5,4.1,2.9)$ & $2.88, \mathrm{~m}$ & & $2.84, \mathrm{dd}(17.3,6.0)$ \\
\hline $7 \beta$ & $2.5, \mathrm{~m}$ & 2.30, $\mathrm{m}$ & & $2.67, \mathrm{~m}$ \\
\hline 11 & $7.03, \mathrm{~s}$ & $6.85, \mathrm{~s}$ & $6.80, \mathrm{~s}$ & $6.54, \mathrm{~s}$ \\
\hline 15 & $6.61, \mathrm{dd}(17.9,11.4)$ & $6.66, \mathrm{dd}(18.0,11.4)$ & & $6.58, \mathrm{dd}(18.0,11.4)$ \\
\hline $16 \alpha$ & $5.55, \mathrm{dd}(11.4,2.0)$ & $5.57, \mathrm{dd}(11.4,2.0)$ & & 5.56, dd $(11.4,2.0)$ \\
\hline $16 \beta$ & $5.17, \mathrm{dd}(17.9,2.0)$ & $5.19, \mathrm{dd}(18.0,2.0)$ & & $5.18, \mathrm{dd}(18.0,2.0)$ \\
\hline 17 & $2.19, \mathrm{~s}$ & $2.19, \mathrm{~s}$ & $2.13, \mathrm{~s}$ & $2.19, \mathrm{~s}$ \\
\hline 18 & $0.77, \mathrm{~s}$ & $1.02, \mathrm{~s}$ & $0.85, \mathrm{~s}$ & $0.78, \mathrm{~s}$ \\
\hline 19 & $1.11, \mathrm{~s}$ & $1.20, \mathrm{~s}$ & $1.29, \mathrm{~s}$ & $1.25, \mathrm{~s}$ \\
\hline 20 & & & & $1.18, \mathrm{~s}$ \\
\hline OMe-12 & & & $3.93, \mathrm{~s}$ & \\
\hline OH-3 & & & & $3.47, \mathrm{~s}$ \\
\hline $\mathrm{OH}-14$ & & & $12.77, \mathrm{~s}$ & \\
\hline
\end{tabular}

Table 2. ${ }^{13} \mathrm{C}(150 \mathrm{MHz}) \mathrm{NMR}$ data for compounds $1-4$ in $\mathrm{CDCl}_{3}$.

\begin{tabular}{ccccc}
\hline \multirow{2}{*}{ No. } & $\mathbf{1}$ & $\mathbf{2}$ & $\mathbf{3}$ & $\mathbf{4}$ \\
\cline { 2 - 5 } & $\boldsymbol{\delta}_{\mathrm{C}}$ & $\boldsymbol{\delta}_{\mathrm{C}}$ & $\boldsymbol{\delta}_{\mathrm{C}}$ & $\boldsymbol{\delta}_{\mathrm{C}}$ \\
\hline 1 & 116.5 & 79.9 & 119.6 & 52.1 \\
2 & 32.3 & 34.2 & 199.1 & 210.7 \\
3 & 74.9 & 86.9 & 79.7 & 82.8 \\
4 & 37.2 & 44.6 & 41.3 & 44.9 \\
5 & 46.2 & 43.8 & 46.0 & 48.8 \\
6 & 24.0 & 22.7 & 37.4 & 19.2 \\
7 & 28.9 & 28.3 & 201.4 & 29.1 \\
8 & 127.3 & 122.4 & 110.5 & 125.1 \\
9 & 132.9 & 130.9 & 136.0 & 145.4 \\
10 & 134.5 & 87.1 & 153.6 & 43.8 \\
11 & 108.3 & 112.1 & 99.8 & 109.4 \\
12 & 152.1 & 152.4 & 163.6 & 152.5 \\
13 & 121.3 & 132.7 & 117.6 & 120.2 \\
14 & 139.5 & 138.8 & 162.1 & 139.7 \\
15 & 135.3 & 135.1 & & 135.3 \\
16 & 120.1 & 120.5 & & 120.1 \\
17 & 13.1 & 13.0 & 8.1 & 13.0 \\
18 & 13.4 & 24.2 & 14.1 & 16.4 \\
19 & 24.4 & 24.5 & 24.4 & 29.3 \\
20 & & & & 26.1 \\
OMe-12 & & & 56.0 & \\
\hline
\end{tabular}




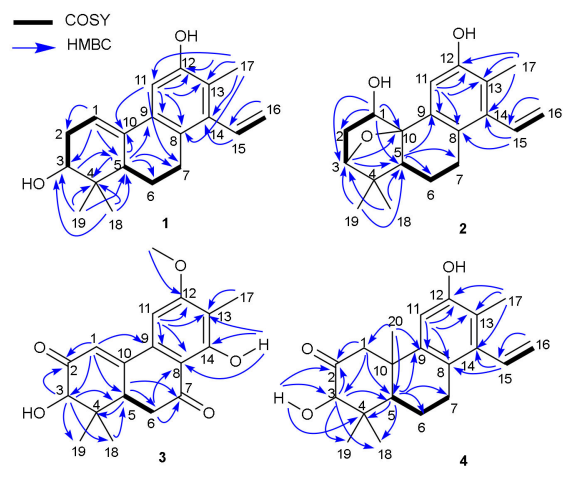

Figure 2. Selected ${ }^{1} \mathrm{H}_{-}{ }^{1} \mathrm{H}$ COSY and HMBC correlations of compounds 1-4.
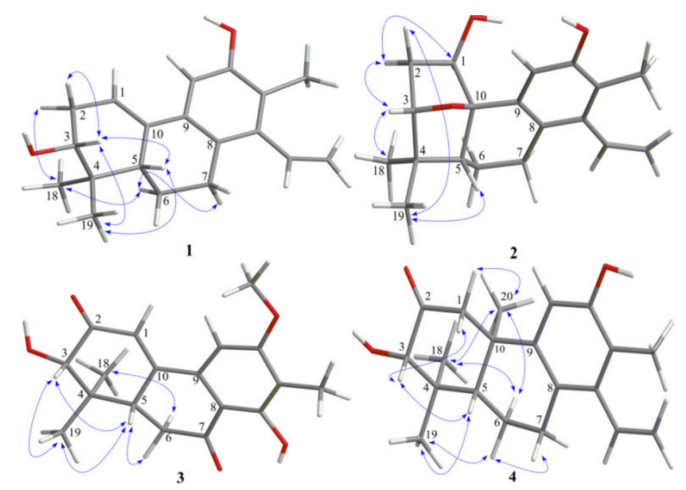

Figure 3. Key ROESY correlations of compounds 1-4.
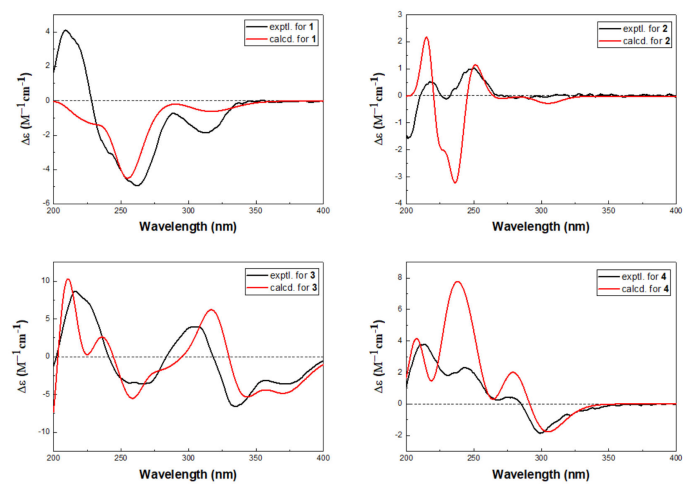

Figure 4. Experimental and calculated ECD spectra of compounds 1-4.

Compound 2 was obtained as a yellow powder with a molecular formula of $\mathrm{C}_{19} \mathrm{H}_{24} \mathrm{O}_{3}$ on the basis of the positive HRESIMS peak at $m / z 323.1616[\mathrm{M}+\mathrm{Na}]^{+}$(calcd. for $\mathrm{C}_{19} \mathrm{H}_{24} \mathrm{O}_{3} \mathrm{Na}$, 323.1618), indicating eight degrees of unsaturation and showing 16 mass units more than those of compound 1. The IR absorptions indicated the presence of hydroxyl $\left(3438 \mathrm{~cm}^{-1}\right)$ and olefinic $\left(1631\right.$ and $\left.1531 \mathrm{~cm}^{-1}\right)$ groups. The ${ }^{1} \mathrm{H}$ and ${ }^{13} \mathrm{C}$ NMR spectral data of 2 (Tables 1 and 2) showed, in addition to the presence of one terminal vinyl group $\left(\delta_{\mathrm{H}} 6.66, \mathrm{dd}, J=18.0,11.4 \mathrm{~Hz}, \mathrm{H}-15 ; \delta_{\mathrm{H}} 5.57, \mathrm{dd}, J=11.4,2.0 \mathrm{~Hz}, \mathrm{H}-16 \alpha ; \delta_{\mathrm{H}}\right.$ $5.19, \mathrm{dd}, J=18.0,2.0 \mathrm{~Hz}, \mathrm{H}-16 \beta ; \delta_{\mathrm{C}} 135.1$ and 120.5$)$ and one penta-substituted benzene ring $\left(\delta_{\mathrm{H}} 6.85\right.$, s; $\delta_{\mathrm{C}} 152.4,138.8,132.7,130.9,122.4$, and 112.1), easily recognized signals for three singlet methyls, three aliphatic methylenes, three methines (two oxygenated), and two quaternary carbons (one oxygenated and one aliphatic). These data accounted for four out of eight degrees of unsaturations, suggesting that 2 was a tetracyclic compound. A comparison of the ${ }^{1} \mathrm{H}$ and ${ }^{13} \mathrm{C}$ data of 2 (Tables 1 and 2) with those of $\mathbf{1}$ indicated they shared similar structural skeleton and the major change in ring A. Signals for the $\Delta^{1,10}$ double bond in 1 were replaced by those for an oxygenated quaternary carbon $\left(\delta_{C} 87.1\right)$ and an 
oxymethine $\left(\delta_{\mathrm{H}} 4.32, \mathrm{dd}, J=10.3,3.6 \mathrm{~Hz} ; \delta_{\mathrm{C}} 79.9\right)$ in 2 . An ether bridge could be present between $\mathrm{C}-3$ and $\mathrm{C}-10$ which was further supported by its $\mathrm{HMBC}$ correlation from $\mathrm{H}-3\left(\delta_{\mathrm{H}} 3.86\right)$ to $\mathrm{C}-1 / \mathrm{C}-5 / \mathrm{C}-10 / \mathrm{C}-19$ and ${ }^{1} \mathrm{H}-{ }^{1} \mathrm{H}$ COSY correlations $\mathrm{H}-1 / \mathrm{H}_{2}-2 / \mathrm{H}-3$. The extra hydroxyl group was assigned to $\mathrm{C}-1$ by the HMBC correlations from $\mathrm{H}-1\left(\delta_{\mathrm{H}} 4.32\right)$ to $\mathrm{C}-2\left(\delta_{\mathrm{C}} 34.2\right) / \mathrm{C}-3\left(\delta_{\mathrm{C}} 86.9\right) / \mathrm{C}-5\left(\delta_{\mathrm{C}} 43.8\right) / \mathrm{C}-10\left(\delta_{\mathrm{C}} 87.1\right)$ and the downfield carbon chemical shift of $C-1\left(\delta_{\mathrm{C}} 79.9\right)$ (Figure 2). The aforementioned information indicated that 2 was a phenylethylene-bearing 20-nor-diterpenoid possessing a rare 3,20-oxybridge.

The ROESY correlations (Figure 3 ) of $\mathrm{H}-1 / \mathrm{H}-2 \alpha, \mathrm{H}-2 \alpha / \mathrm{H}-3$, and $\mathrm{H}-3 / \mathrm{H}_{3}-18$ suggested these protons to be $\alpha$-oriented, while ROESY correlations of $\mathrm{H}-2 \beta / \mathrm{H}_{3}-19$ and $\mathrm{H}-5 / \mathrm{H}_{3}-19$ suggested these protons to be $\beta$-oriented. The absolute configuration of $\mathbf{2}$ was finally assigned by comparison of the experimental ECD spectrum with TDDFT calculated spectrum. In the $200-400 \mathrm{~nm}$ regions, the calculated spectra showed the same trend as the experimental one, although rotatory strengths of the third positive Cotton effect around $230 \mathrm{~nm}$ were overestimated (Figure 4), implying the absolute configuration of 2 as $1 R, 3 S, 5 R$, and $10 R$. The structure of 2 was thus established and named aspidoptoid B as shown in Figure 1.

Compound 3, a yellow powder, possessed a molecular formula of $\mathrm{C}_{18} \mathrm{H}_{20} \mathrm{O}_{5}$ as deduced from the negative HRESIMS peak at $m / z 315.1234[\mathrm{M}-\mathrm{H}]^{-}$(calcd. for $\mathrm{C}_{18} \mathrm{H}_{19} \mathrm{O}_{5}, 315.1238$ ). The IR spectrum revealed the presence of hydroxyl $\left(3433 \mathrm{~cm}^{-1}\right)$ and conjugated carbonyl $\left(1631 \mathrm{~cm}^{-1}\right)$. The ${ }^{13} \mathrm{C}$ NMR (Table 2) distinguished 18 resonances due to the four methyls (one $O$-methyl), one methylene, four methines (one oxygenated and two olefinic), and nine quaternary carbons (two keto and six olefinic). Analysis of its ${ }^{1} \mathrm{H}$ and ${ }^{13} \mathrm{C}$ NMR spectra indicated that 3 was a congener of domohinone [10] with the only difference being an $\mathrm{OH}-14$ in 3 instead of an aromatic proton $\mathrm{H}-14$ in domohinone which was confirmed by the HMBC correlations (Figure 2$)$ from $\mathrm{OH}-14\left(\delta_{\mathrm{H}} 12.77\right)$ to $\mathrm{C}-8\left(\delta_{\mathrm{C}} 110.5\right), \mathrm{C}-13\left(\delta_{\mathrm{C}} 117.6\right)$, and $\mathrm{C}-14\left(\delta_{\mathrm{C}} 162.1\right)$.

The relative configuration of 3 was mainly established by a ROESY spectrum. The ROESY correlations (Figure 3) of $\mathrm{H}-3 / \mathrm{H}-5, \mathrm{H}-3 / \mathrm{H}_{3}-19, \mathrm{H}-5 / \mathrm{H}_{3}-19$, and $\mathrm{H}-5 / \mathrm{H}-6 \beta$ indicated that these protons were all $\beta$-oriented, whereas the ROESY correlations of $\mathrm{H}-6 \alpha / \mathrm{H}_{3}-18$ revealed the $\alpha$-orientation of the corresponding protons. The absolute configurations of 3 were elucidated as $3 S, 5 S$ based on the similar positive Cotton effects at 220 and $300 \mathrm{~nm}$ between the experimental ECD spectrum and the calculated spectrum (Figure 4). The structure of $\mathbf{3}$ was thus established and named aspidoptoid $C$ as depicted in Figure 1.

Compound 4, a yellow powder, had the molecular formula $\mathrm{C}_{20} \mathrm{H}_{26} \mathrm{O}_{3}$, as determined by positive HRESIMS peak at $m / z 337.1772[\mathrm{M}+\mathrm{Na}]^{+}$(calcd. for $\mathrm{C}_{20} \mathrm{H}_{26} \mathrm{O}_{3} \mathrm{Na}, 337.1774$ ). The IR spectrum exhibited absorption bands for hydroxyl $\left(3428 \mathrm{~cm}^{-1}\right)$ and ketone carbonyl $\left(1713\right.$ and $\left.1640 \mathrm{~cm}^{-1}\right)$. The 1D NMR spectra revealed 20 carbon signals assignable to four methyls, four methylenes (one olefinic), four methines (one oxygenated and two olefinic), and eight quaternary carbons (one keto and six olefinic). Comparing with spruceanol (5) [9], the major difference was the presence of a ketone canbonyl $\left(\delta_{C} 210.7\right)$ in 4 instead of a methylene $\left(\delta_{C} 27.98\right)$ in 5 , indicating that 4 was the oxygenated derivative of 5 . The ketone carbonyl was assigned at $\mathrm{C}-2$ by $\mathrm{HMBC}$ correlations from $\mathrm{H}-1\left(\delta_{\mathrm{H}} 3.05, \mathrm{~d}\right.$, $\left.J=12.3 \mathrm{~Hz}, \mathrm{H}-1 \alpha ; \delta_{\mathrm{H}} 2.63, \mathrm{~d}, J=12.3 \mathrm{~Hz}, \mathrm{H}-1 \beta\right), \mathrm{H}-3\left(\delta_{\mathrm{H}} 3.97, \mathrm{~s}\right)$, and $\mathrm{OH}-3\left(\delta_{\mathrm{H}} 3.47, \mathrm{~s}\right)$ to C-2 $\left(\delta_{\mathrm{C}} 210.7\right)$. The planar structure of 4 was further secured by detailed analyses of its $2 \mathrm{D}$ NMR data (Figure 2). The ROESY correlations of $\mathrm{H}-1 \beta / \mathrm{H}-3, \mathrm{H}-3 / \mathrm{H}-5, \mathrm{H}-5 / \mathrm{H}_{3}-19, \mathrm{H}-6 / \mathrm{H}_{3}-19$, and $\mathrm{H}-7 / \mathrm{H}-6 \beta$ showed that they were cofacial and randomly assigned to be $\beta$-oriented. Subsequently, the ROESY cross-peaks of $\mathrm{H}-1 \alpha / \mathrm{H}_{3}-20, \mathrm{H}-6 \alpha / \mathrm{H}_{3}-18, \mathrm{H}-6 \alpha / \mathrm{H}_{3}-20$, and $\mathrm{H}_{3}-18 / \mathrm{H}_{3}-20$ indicated that $\mathrm{H}_{3}-18$ and $\mathrm{H}_{3}-20$ were $\alpha$-oriented (Figure 3). The absolute configuration of 4 was determined by ECD spectrum (Figure 4). The calculated spectra showed the same trend as the experimental one which confirmed the absolute configuration of 4 as $3 S, 5 S$, and 10R. The structure of 4 was established and named aspidoptoid D as depicted in Figure 1.

Two known compounds were identified to be spruceanol (5) [9] and sonderianol (6) [11] by comparing their spectroscopic data with those in the literature. 
The biosynthetic pathways for compounds 1-4 are shown in Scheme 1. The precursors for compounds 1-4 were considered to be co-isolated cleistanthane-type diterpenoid spruceanol (5), which was transformed to intermediate $\mathbf{i}$ by the oxidation process and then decarboxylation to afford compound 1. Compound 1 would undergo oxidation and dehydration procedures to give compound 2. The methylation and Wacker oxidation processes of $\mathbf{1}$ produced intermediate iii which underwent Baeyer-Villiger oxidation and hydrolysis processes to yield intermediate v. Compound 3 was finally obtained by the further oxidation reaction of intermediate v. Compounds 4 and 6 were also produced after a series of oxidation of compound 5 [12].

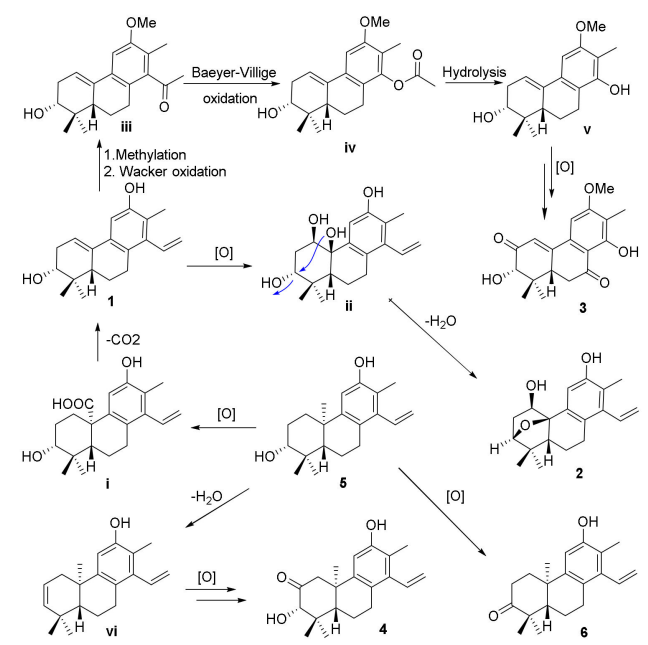

Scheme 1. Plausible biosynthetic pathways of compounds 1-4.

All the isolates were evaluated for their inhibitory effects on nitric oxide (NO) production stimulated by LPS in RAW 264.7 cells with L-NMMA (NG-monomethyl L-arginine) as the reference compound. Among those compounds, compound 5 exhibited weak NO inhibition and the rest of the compounds were inactive at $50 \mu \mathrm{M}$ (Table 3). In addition, they were also tested for their cytotoxic activity against five human tumor cell lines (i.e., HL-60, SMMC-7721, A-549, MCF-7, and SW-480) using the MTS method. However, all the compounds were non-cytotoxic $\left(\mathrm{IC}_{50}>40 \mu \mathrm{M}\right)$ (Supplementary Materials Table S1).

Table 3. NO inhibitory effects of compounds 1-6.

\begin{tabular}{ccc}
\hline Compound & Concentration $(\boldsymbol{\mu M})$ & NO Inhibition Rate $\mathbf{( \% )}$ \\
\hline $\mathbf{1}$ & 50 & $-5.94 \pm 2.27$ \\
$\mathbf{2}$ & 50 & $-0.56 \pm 1.09$ \\
$\mathbf{3}$ & 50 & $-3.50 \pm 1.60$ \\
$\mathbf{4}$ & 50 & $-7.78 \pm 1.50$ \\
$\mathbf{5}$ & 50 & $31.54 \pm 1.55$ \\
$\mathbf{6}$ & 50 & $-11.45 \pm 1.93$ \\
L-NMMA $^{\mathrm{a}}$ & 50 & $51.23 \pm 0.65$ \\
\hline
\end{tabular}

a Positive control.

\section{Materials and Methods}

\subsection{General Experimental Procedures}

Optical rotations were obtained with a Rudolph Autopol VI polarimeter (Rudolph Research Analytical, Hackettstown, NJ, USA). The UV spectra were measured with a Shimadzu UV-2401A instrument (Shimadzu Corporation, Kyoto, Japan). The IR spectra (KBr) were determined on a Bruker Tensor-27 infrared spectrometer (Bruker Corporation, Karlsruhe, Germany). The ECD spectra were 
measured with a Chirascan circular dichroism spectrometer (Applied Photophysics Ltd., Surrey, UK). The NMR spectra were obtained on a Bruker Avance spectrometer operating (Bruker Corporation, Karlsruhe, Germany) at $600 \mathrm{MHz}$ for ${ }^{1} \mathrm{H}$ NMR and $150 \mathrm{MHz}$ for ${ }^{13} \mathrm{C}$ NMR, using tetramethylsilane as an internal standard. The ESIMS and HRESIMS were carried out on a Shimadzu UPLC-IT-TOF mass spectrometer (Shimadzu Corporation, Kyoto, Japan). Semi-preparative HPLC was performed on a Waters 600 pump system with a 2996 photodiode array detector using a YMC-Pack ODS-A column $(300 \times 10 \mathrm{~mm}, \mathrm{~S}-5 \mu \mathrm{M}$, YMC Co., Ltd., Komatsu, Japan). The TLC and column chromatography (CC) were performed on plates precoated with silica gel GF254 $(10-40 \mu \mathrm{m})$ and over silica gel (200-300 mesh, Qingdao Marine Chemical Factory, Qingdao, China), Sephadex LH-20 gel (40-70 $\mu \mathrm{M}$, Amersham Pharmacia Biotech AB, Uppsala, Sweden), C18 reversed-phase silica gel (40-63 $\mu \mathrm{m}$; Merck, Darmstadt, Germany), and MCI gel (CHP20/P120, 75-150 $\mu \mathrm{m}$, high-porous polymer, Mitsubishi Chemical Corporation, Tokyo, Japan). All solvents used were of analytical grade (Shanghai Chemical Reagents Co. Ltd., Shanghai, China), and all solvents used for the HPLC were of spectral grade (J \& K Scientific Ltd., Beijing, China).

\subsection{Plant Material}

The vine of A. obcordata was collected from Xishuangbanna Tropical Botanical Garden (XTBG), Chinese Academy of Science (CAS), Mengla Country, Yunnan Province, People's Republic of China, in September 2016, and they were identified by one of the authors (C.-F.X.). A voucher specimen (No. HITBC-094469) was deposited in the herbarium of XTBG.

\subsection{Extraction and Isolation}

Air-dried powder of $A$. obcordata vine $(5.5 \mathrm{~kg})$ was extracted three times with $95 \% \mathrm{EtOH}(20 \mathrm{~L}$, $v / v$ ) (one week for each time) at room temperature. The extracts were combined and concentrated under reduced pressure. Then, the concentrate $(480.0 \mathrm{~g})$ was suspended in $\mathrm{H}_{2} \mathrm{O}(2 \mathrm{~L})$ and successively partitioned with ethyl acetate and $n$ - $\mathrm{BuOH}$. The ethyl acetate fraction $(150.0 \mathrm{~g})$ was separated over a MCI gel column $(8 \mathrm{~cm} \times 100 \mathrm{~cm})$ chromatograph and eluted with $\mathrm{EtOH} / \mathrm{H}_{2} \mathrm{O}(40 / 60$ to $90 / 10, v / v$, each $8 \mathrm{~L})$ to obtain fractions 1 to 6 . Fraction $6(33.2 \mathrm{~g})$ was then subjected to silica gel CC $(6 \mathrm{~cm} \times 70 \mathrm{~cm}$, 200-300 mesh) and eluted with a gradient of $\mathrm{CH}_{2} \mathrm{Cl}_{2} / \mathrm{MeOH}(1: 0$ to $1: 1, v / v$, each $4 \mathrm{~L})$ to produce fractions A-E (8.5, 5.0, 10.4, 2.7, and $3.2 \mathrm{~g}$, respectively). Fraction $\mathrm{B}(5.0 \mathrm{~g})$ was subjected to silica gel CC $\left(4 \mathrm{~cm} \times 70 \mathrm{~cm}, 200-300\right.$ mesh) and eluted with a gradient of $\mathrm{CH}_{2} \mathrm{Cl}_{2} / \mathrm{MeOH}(1: 0$ to $20: 1, v / v$, each $1 \mathrm{~L})$ to produce fractions B1-B3. Fraction B1 $(1.2 \mathrm{~g})$ was further purified by semi-preparative HPLC $\left(10 \mathrm{~mm} \times 300 \mathrm{~mm}, \mathrm{MeCN} / \mathrm{H}_{2} \mathrm{O}, 90: 10, v / v, 3 \mathrm{~mL} / \mathrm{min}\right)$ to yield $\mathbf{1}(5 \mathrm{mg}), \mathbf{5}(10 \mathrm{mg})$, and $2(4 \mathrm{mg})$, respectively. Fraction C (10.4 g) was further separated by CC over a Sephadex LH-20 $(2 \mathrm{~cm} \times 100 \mathrm{~cm})$ column ( $\mathrm{MeOH}$ as eluent) to give three major subfractions, purification of which by semi-preparative $\mathrm{HPLC}\left(10 \mathrm{~mm} \times 300 \mathrm{~mm}, \mathrm{MeCN} / \mathrm{H}_{2} \mathrm{O}, 82: 18, v / v, 3 \mathrm{~mL} / \mathrm{min}\right)$ yielded $3(12 \mathrm{mg}), 6(8 \mathrm{mg})$, and 4 (7 mg), respectively.

Aspidoptoid A (1): Yellow powder; $\left.[\alpha]^{25.2}{ }_{\mathrm{D}}-27.1^{\circ}(c) 0.16, \mathrm{MeOH}\right) ; \mathrm{UV}(\mathrm{MeOH}) \lambda_{\max }(\log \varepsilon) 232$ (3.8), 259 (3.5), 314 (3.1) nm; IR (KBr) $v_{\max }$ 3431, 2964, 2927, 2870, 1708, 1630, 1404, 1384, 1364, 1322, 1293, 1117, 995, 963, 923, 895, 857, $833 \mathrm{~cm}^{-1}$; negative HRESIMS m/z 283.1704 [M - H] ${ }^{-}$(calcd. for $\left.\mathrm{C}_{19} \mathrm{H}_{23} \mathrm{O}_{2}, 283.1704\right)$; for ${ }^{1} \mathrm{H}$ and ${ }^{13} \mathrm{C}$ NMR data, see Tables 1 and 2.

Aspidoptoid B (2): Yellow powder; $[\alpha]^{24.9}{ }_{\mathrm{D}}-20.5^{\circ}\left(\right.$ c 0.07, MeOH); UV (MeOH) $\lambda_{\max }(\log \varepsilon) 205$ (3.2), 268 (2.3) nm; IR (KBr) $v_{\max } 3438,2961,2925,2855,1722,1705,1631,1550,1531,1463,1408,1384$, $1262,1097,1023,872,804,559 \mathrm{~cm}^{-1}$; positive HRESIMS m/z $323.1616[\mathrm{M}+\mathrm{Na}]^{+}$(calcd. for $\mathrm{C}_{19} \mathrm{H}_{24} \mathrm{O}_{3} \mathrm{Na}$, 323.1618); for ${ }^{1} \mathrm{H}$ and ${ }^{13} \mathrm{C}$ NMR data, see Tables 1 and 2.

Aspidoptoid C (3): Yellow powder; $[\alpha]^{25.1} \mathrm{D}-14.2^{\circ}\left(\right.$ c 0.13, MeOH); UV (MeOH) $\lambda_{\max }(\log \varepsilon) 205$ (3.2), 269 (3.3), 329 (3.0), 356 (2.8) nm; IR (KBr) $v_{\max }$ 3433, 2959, 2925, 2854, 1631, 1220, 1191, 1163, 1143, $1128, \mathrm{~cm}^{-1}$; negative HRESIMS $\mathrm{m} / \mathrm{z} 315.1234[\mathrm{M}-\mathrm{H}]^{-}$(calcd. for $\mathrm{C}_{18} \mathrm{H}_{19} \mathrm{O}_{5}, 315.1238$ ); for ${ }^{1} \mathrm{H}$ and ${ }^{13} \mathrm{C}$ NMR data, see Tables 1 and 2. 
Aspidoptoid D (4): Yellow powder; $[\alpha]^{24.7}{ }_{\mathrm{D}}-9.7^{\circ}\left(c\right.$ 0.15, MeOH); UV (MeOH) $\lambda_{\max }(\log \varepsilon) 205$ (3.8), 238 (3.3), 298 (3.0), 354 (2.7) nm; IR (KBr) $v_{\max } 3428,3084,2968,2926,2872,2854,1713,1640,1592$, 1511, 1466, 1162, 1001, 965, 923, 856, 803, 685, $621 \mathrm{~cm}^{-1}$; positive HRESIMS $\mathrm{m} / \mathrm{z} 337.1772[\mathrm{M}+\mathrm{Na}]^{+}$ (calcd. for $\mathrm{C}_{20} \mathrm{H}_{26} \mathrm{O}_{3} \mathrm{Na}$, 337.1774); for ${ }^{1} \mathrm{H}$ and ${ }^{13} \mathrm{C}$ NMR data, see Tables 1 and 2.

\subsection{Assay for Inhibition Ability toward LPS-Induced NO Production and Cytotoxicity Testing}

The RAW 264.7 macrophages (obtained from Kunming Institute of Zoology, Chinese Academy of Sciences) were maintained in DEMEM/high-glucose medium (Invitrogen, Carlsbad, CA, USA) supplemented with $10 \%(v / v)$ newborn calf serum and antibiotics $(100 \mathrm{U} / \mathrm{mL}$ penicillin and $0.1 \mathrm{~g} / \mathrm{L}$ streptomycin) at $37^{\circ} \mathrm{C}$ in the presence of $5 \% \mathrm{CO}_{2}$. The cell viability was determined by MTS assay before the nitric oxide (NO) production assay, and the $\mathrm{NO}$ production was measured by the accumulation of nitrite in the culture supernatants using the Griess Reagent System as previously reported [13]. All experiments were performed in three independent replicates, and L-NMMA (NG-monomethyl L-arginine) (Sigma) was used as a positive control. Statistical analysis was calculated using SPSS 21.0 software (International Business Machines Corporation, Armonk, NY, USA).

\subsection{Cytotoxicity Assay}

Cytotoxic activity of the compounds against the HL-60, SMMC-7721, A-549, MCF-7, and SW480 cell lines were evaluated using the MTS method [14]. Briefly, all cells were cultured in RPMI 1640 medium containing $10 \%$ fetal bovine serum and $100 \mathrm{U} / \mathrm{mL}$ penicillin/streptomycin in a humidified incubator in a $5 \% \mathrm{CO}_{2}$ atmosphere at $37^{\circ} \mathrm{C}$. Then, $100 \mu \mathrm{L}$ of adherent cells was seeded into each well $\left(1 \times 10^{4}\right.$ cells/well $)$ of 96 well cell culture plates and allowed to adhere for $12 \mathrm{~h}$ before test drug addition. Each tumor cell line was exposed to a test compound at concentrations of $0.064,0.32,1.6,8$, and $40 \mu \mathrm{M}$ in DMSO in triplicate for $48 \mathrm{~h}$, with cisplatin as the positive control. After $48 \mathrm{~h}$ incubation, $20 \mu \mathrm{L}$ of MTS [3-(4,5-dimethylthiazol-2-yl)-5-(3-carboxymethoxy-phenyl)-2-(4-sulfophenyl)-2H-tetrazolium] solution was added to each well which were incubated for another $4 \mathrm{~h}$ to give a formazan product. Then $100 \mu \mathrm{L}$ of $20 \%$ SDS was added to each well and incubated $12 \mathrm{~h}$ at room temperature for the formazan product to dissolve completely. The OD value of each well was measured at $490 \mathrm{~nm}$ using a Biorad 680 instrument (Bio-Rad Laboratories, Inc., Hercules, CA, USA). The $\mathrm{IC}_{50}$ value of each compound was calculated by the Reed and Muench method [15].

\section{Conclusions}

In summary, four new ones aspidoptoids A-D (1-4) together with two known analogues were isolated and characterized by solid data from A. obcordata vine. Compounds $\mathbf{1}$ and $\mathbf{2}$ are the first examples of phenylethylene-bearing 20-nor-diterpenoids, and 2 possesses a rare 3,10-oxybridge. The plausible biosynthetic pathways for compounds 1-4 were also proposed with compound 5 as the precursor. All the isolates were evaluated for their cytotoxicity and NO inhibitory effects. Among those compounds, compound 5 exhibited weak NO inhibitory effects at $50 \mu \mathrm{M}$.

Supplementary Materials: The following are available online, Figure S1-S41: 1D and 2D NMR, HRESIMS, UV, IR spectra, ECD data of new compounds 1-4. Table S1: Cytotoxic activity of compounds 1-6

Author Contributions: Conceptualization, P.S., Y.-K.X. and D.-H.C.; Formal analysis, P.S., Y.-D.X.; Funding acquisition, H.-B.H. and Y.-K.X.; Investigation and methodology: P.S. and D.-H.C. (isolation and structural elucidation), Z.-Y.Z. and J.-N.W. (bioassay); Resources, X.-C.S. and C.-F.X.; Software, Y.-D.X.; Supervision, Y.-K.X.; Writing-original draft, P.S. and D.-H.C.; Writing-review and editing, Y.-K.X. and D.-H.C. All authors have read and agreed to the published version of the manuscript.

Funding: This work was supported financially by Systematic Evaluation of Ethnic Medicinal Plant Resources in Tropical Regions and Development of Health Products for the Public (2017XTBG-F02), Conservation and Application of National Strategic Tropical Plant Resources: Theory and Practice (2017XTBG-F05) and the International Partnership Program of Chinese Academy of Sciences (153631KYSB20160004).

Acknowledgments: The authors gratefully acknowledge the Central Laboratory of Xishuangbanna Tropical Botanical Garden, Chinese Academy of Sciences, for technical support of this study. 
Conflicts of Interest: The authors declare no conflict of interest.

\section{References}

1. Chen, S.K.; Funston, A.M. Chinese Flora (Zhongguo Zhiwu Zhi); Science Press: Beijing, China, 1997; Volume 43, p. 3.

2. Li, Y.H.; Li, G.; Song, M.F.; Li, X.L.; Zhan, X.; Lu, J.; Chen, X. Acute toxicity study of Aspidopterys obcordata aqueous extract in Sprague-Dawley rats. J. Tradit. Chin. Med. 2016, 36, 377-381. [PubMed]

3. Li, H.; Peng, C.Z.; Guan, Y.H.; Niu, Y.F.; Zhang, L.X. Resources investigation on Aspidopterys obcordata. Shi Zhen Guo Yi Guo Yao 2011, 22, 2999-3000.

4. Lei, Y.; Liang, J.H.; Tian, Y.J.; Luo, H.B.; He, X.X. A new rhamnoside from Aspidopterys obcordata. Chin. Herb. Med. 2019, 50, 1039-1042.

5. Li, X.H.; Niu, Y.F.; Song, M.F.; Zhang, L.X. Chemical constituents of Dai medicine Aspidopterys obcordata. Asia-Pacific Tradit. Med. 2016, 12, 30-32.

6. Hu, M.; Li, Y.; Sun, Z.; Huo, X.; Zhu, N.; Sun, Z.; Liu, Y.; Wu, H.; Xu, X.; Ma, G. New polyoxypregnane glycosides from Aspidopterys obcordata vines with antitumor activity. Fitoterapia 2018, 129, 203-209. [CrossRef] [PubMed]

7. Wu, R.; Ye, Q.; Chen, N.Y.; Zhang, G.L. Study on the chemical constituents of Aspidopterys obcordata Hemsl. Nat. Prod. Rsc. Dev. 2001,13,14-16.

8. Li, Y.; Ma, G.; Lv, Y.; Su, J.; Li, G.; Chen, X. Efficacy of obcordata A from Aspidopterys obcordata on kidney stones by inhibiting NOX4 expression. Molecules 2019, 24, 1957. [CrossRef] [PubMed]

9. Gunasekera, S.P.; Cordell, G.A.; Farnsworth, N.R. Potential anticancer agents. XIV. Isolation of spruceanol and montanin from Cunuria spruceana (Euphorbiaceae). J. Nat. Prod. 1979, 42, 658-662. [CrossRef] [PubMed]

10. Long, L.; Lee, S.K.; Chai, H.B.; Rasoanaivo, P.; Gao, Q.; Navarro, H.; Wall, M.E.; Wani, M.C.; Farnsworth, N.R.; Cordell, G.A. Novel bioactive phenanthrene derivatives from Domohinea perrieri. Tetrahedron 1997, 53, 15663-15670. [CrossRef]

11. Craveiro, A.A.; Silveira, E.R. Two cleistanthane type diterpenes from Croton sonderianus. Phytochemistry 1982, 21, 2571-2574. [CrossRef]

12. Dewick, P.M. Medicinal Natural Products: A Biosynthetic Approach, 3rd ed.; John Wiley \& Sons: Chichester, UK, 2002; pp. 22-26.

13. Cao, D.H.; Sun, P.; Liao, S.G.; Gan, L.S.; Yang, L.; Yao, J.N.; Zhang, Z.Y.; Li, J.F.; Zheng, X.L.; Xiao, Y.D. Chemical constituents from the twigs and leaves of Trichilia sinensis and their biological activities. Phytochemistry lett. 2019, 29, 142-147. [CrossRef]

14. Cao, D.H.; Liao, S.G.; Yang, L.; Li, X.N.; Wu, B.; Zhang, P.; Guo, J.; Xiao, C.F.; Hu, H.B.; Xu, Y.K. Trichiliasinenoids A-C, three 6, 7-secomexicanolide limonoids with a 7, 29-linkage from Trichilia sinensis. Tetrahedron Lett. 2017, 58, 3283-3286. [CrossRef]

15. Reed, L.; Muench, H. A simple method for determining 50 per cent endpoints. Am. J. Hyg. 1938, $27,493-497$.

Sample Availability: Samples are available from the authors.

(C) 2020 by the authors. Licensee MDPI, Basel, Switzerland. This article is an open access article distributed under the terms and conditions of the Creative Commons Attribution (CC BY) license (http://creativecommons.org/licenses/by/4.0/). 